\title{
Faktor-Faktor yang Mempengaruhi Kurangnya Kesadaran Mahasiswi AKBID Saleha Terhadap Penggunaan Masker di Masa Pandemi COVID-19 di AKBID Saleha Banda Aceh Tahun 2021
}

\author{
Desria Mauliati \\ Akademi Kebidanan Saleha, Banda Aceh, Indonesia \\ Email : desria.stafsaleha88@gmail.com
}

\begin{abstract}
Abstrak-Pengunaan masker adalah salah satu protocol kesehatan yang harus dilakukan oleh semua orang dengan disiplin. Hasil pemantauan Kepatuhan Protokol Kesehatan memakai masker pada mahasiswi di Akademi Kebidanan Saleha Banda Aceh Tahun 2021 sekitar 75\% dari keseluruhan mahasiswi tingkat 1,2 dan 3. Tujuan Penelitian: untuk mengetahui pengaruh pengetahuan, lingkungan dan perilaku pada mahasiswi akbid Saleha Banda Aceh. Metode Penelitian: penelitian ini menggunakan metode analitik dengan pendekatan Cros Sectional yang dilakukan pada tanggal 26-27 Agustus 2021. Populasi dalam penelitian ini adalah seluruh mahasiswi Akbid Saleha yang berjumlah 92 orang. Pengambilan sampel menggunakan total sampling. Analisa data menggunakan analisa univariat dan bivariat dengan metode chi-square. Hasil Penelitian: Hasil uji statistic dengan Chi-Square diperoleh nilai p Value $=0,000<0,05$, ada pengaruh pengetahuan mahasiswi Akbid Saleha dengan kurangnya kesadaran penggunaan masker. Sedangkan hasil uji statistik dengan Chi-Square di peroleh nilai p Value $=0,000<0,05$, ada pengaruh lingkungan dengan kurangnya kesadaran penggunaan masker pada mahasiswi Akbid Saleha. Dan hasil uji statistic dengan Chi Square di peroleh nilai p Value $=0,000<0,05$, ada pengaruh perilaku dengan kurangnya kesadaran penggunaan masker pada mahasiswi Akbid Saleha.
\end{abstract}

Kata Kunci: Pengetahuan; Lingkungan; Perilaku; Penggunaan Masker

\begin{abstract}
The use of masks is one of the health protocols that must be followed by everyone with discipline. The results of monitoring Compliance with Health Protocols for wearing masks on female students at the Saleha Midwifery Academy Banda Aceh in 2021 are around $75 \%$ of all grades 1,2 and 3 students. Research Objectives: to determine the effect of knowledge, environment and behavior on female students at AkbidSaleha Banda Aceh. Research Methods: This study used an analytical method with a Cross Sectional approach which was carried out on 26-27 August 2021. The population in this study were all AkbidSaleha students who totaled 92 people. Sampling using total sampling.Analysis of data using univariate and bivariate analysis with the chi-square method. Results: The results of statistical tests with Chi-Square obtained $p$ Value $=0.000<0.05$, there is an effect of knowledge of student AkbidSaleha with a lack of awareness of the use of masks. While the results of statistical tests with Chi-Square obtained $p$ Value $=0.000<0.05$, there is an environmental influence with a lack of awareness of the use of masks in AkbidSaleha students. And the results of statistical tests with Chi Square obtained $\mathrm{p}$ value $=0.000<0.05$, there is an influence of behavior with a lack of awareness of the use of masks in AkbidSaleha students.
\end{abstract}

Keywords: Knowledge; Environment; Behavior; Use of Masks

\section{PENDAHULUAN}

Akhir tahun 2019 tepatnya pada bulan Desember dunia dihebohkan dengan berita munculnya wabah pneumonia yang tidak diketahui sebab pastinya. Wabah ini pertama kali ditemukan di kota Wuhan Provinsi Hubei China. Secara resmi, WHO menamakan penyakit ini Covid-19 (Corona Virus Disease 2019) dan nama virus tersebut adalah SARS-CoV-2 (Severe acute respiratory syndrome coronavirus 2) (Lu, 2020).

Menurut WHO, virus Corona adalah keluarga besar virus yang dapat menyebabkan penyakit pada hewan atau manusia. Virus Corona paling terbaru yang ditemukan adalah virus Corona Covid-19. Virus ini termasuk penyakit menular dan baru ditemukan di Wuhan, China pada Desember 2019 yang kemudian menjadi wabah. Hingga kini, kasus baru infeksi Covid-19 masih terus dilaporkan meningkat setiap harinya (Depkes, 2017). Data terbaru WHO (2020), memperlihatkan ada sebanyak 2.775 kasus baru virus corona yang dilaporkan dan total kasus Covid-19 di Indonesia yang telah dikonfirmasi mencapai 177.571 kasus. Jumlah pasien yang telah dinyatakan sembuh adalah sebanyak 128.057 pasien. Sedangkan, kematian akibat virus corona ada sebanyak 7.505 kasus.

Lebih dari 165 juta laporan terkait Covid 19 telah dikumpulkan pada Mei 2021, dengan 469 juta orang dipantau di 514 kabupaten atau kota di 34 provinsi di Indonesia. Angka nasional secara keseluruhan menunjukkan kepatuhan terhadap sebesar 85,9\% dari 375.711.304 orang yang memakai masker, dan dari 315.973.207 (84,1\%) dari 375.711.304 orang yang menjaga jarak fisik, sebagai perkiraan kumulatif. Hasil penelitian menunjukkan adanya variasi tingkat kepatuhan antara kabupaten dan kota di provinsi. Analisis data yang dikumpulkan pada minggu 26 April hingga 2 Mei 2021, menunjukkan kepatuhan pemakaian masker masih rendah yaitu sebanyak 103 orang $(29,6 \%)$ dari 348 kabupaten dan kota di seluruh Indonesia, dan kepatuhan jarak fisik rendah di $99(28,4 \%)$ dari 348 kabupaten dan kota (Aisyah et al., 2021).

Protokol kesehatan yang dianjurkan oleh pemerintah yaitu penggunaan masker, cuci tangan dan menjaga jarak. Penelitian (Dewi \& Apriliani, 2020) menyebutkan bahwa masyarakat masih belum optimal dalam aplikasi protokol kesehatan karena belum adanya fasilitas maksimal yang diberikan oleh pemerintah. Perilaku dalam penganan kesehatan sangat mempengaruhi pencegahan, peningkatan dan penyembuhan dari berbagai kasus penyakit (Notoatmodjo, 2003) seperti diare karena tidak memenuhi standar kesehatan (Bartram et al., 2009). Ketidakpatuhan warga disebabkan oleh motif ekonomi, sikap tidak peduli, merasa berpotensi rendah terhadap penularan virus, serta ketidakpercayaan kepada pemerintah yang mengeluarkan kebijakan dan pernyataan yang tidak konsisten (Sari, 2021). 


\section{Journal of Pharmaceutical and Health Research}

\section{Vol 3, No 1, Februari 2022, pp. 19-22}

ISSN 2721-0715 (media online)

DOI 10.47065/jharma.v3i1.1323

Berdasarkan data yang diperoleh oleh (Saputro et al., 2020), sebagian besar masyarakat telah menerapkan beberapa protokol kesehatan seperti memakai masker, menerapkan social distancing atau physical distancing serta menerapkan etika batuk dan bersin dengan baik. Namun penerapan protokol kesehatan seperti menjaga kebersihan tangan belum terlaksana dengan baik. 52,3 persen dan 56,9 persen partisipan tidak mencuci tangan sebelum makan dan tidak membawa hand sanitizer saat bepergian sebagai bentuk perlindungan diri. Sehingga perlu peran tenaga kesehatan untuk mensosialisasikan atau melakukan penyuluhan dalam bentuk promosi kepada masyarakat (Notoatmodjo, 2007). Oleh karena itu mahasiswa perlu adanya kesadaran dalam mematuhi protokol kesehatan seperti penggunaan masker.

\section{METODOLOGI PENELITIAN}

\subsection{Jenis Penelitian}

Jenis penelitian ini menggunakan matode analitik dengan pendekatan Cross Sectional yaitu pengumpulan data dilakukan sekaligus pada saat yang sama yang akan melihat faktor-faktor kurangnya kesadaran mahasiswi Akbid Saleha dalam penggunaan masker dimasa pandemic Covid-19 di Akbid Selaha Banda Aceh tahun 2021.

\subsection{Tempat dan Waktu}

Penelitian ini dilakukan di Akademi Kebidanan Saleha Banda Aceh pada bulan Mei 2021.

\subsection{Variabel Penelitian}

Populasi dan sekaligus sampel dalam penelitian ini adalah semua mahasiswa/i di Akbid Saleha Banda Aceh. Responden berjumlah sebanyak 92 orang.

\subsection{Instrumen Penelitian}

Instrumen dalam penelitian ini menggunakan angket yang berisi pertanyaan yang diberikan kepada para responden.

\subsection{Analisis Data}

Data yang sudah didapatkan kemudian dianalisis dengan cara perhitungan persentase. Hasil yang didapatkan kemudian disajikan dalam bentuk tabel untuk didiskripsikan dalam pembahasan.

\section{HASIL DAN PEMBAHASAN}

\subsection{Hasil Penelitian}

Hasil penelitian ini mencakup tiga kategori yaitu pengetahuan, lingkungan dan perilaku. Kuesioner dibagikan kepada seluruh mahasiswa di AKBID Saleha sehingga didapatkan hasil sebagai berikut:

\section{Pengetahuan}

Pengetahuan mahasiswa mengenai penggunaan masker di masa andemi COVID 19 ini disajikan dalam Tabel.1

Tabel 1. Distribusi Frekuensi Pengetahuan Penggunaan Masker Pada Mahasiswi Akbid Saleha Tahun 2021

\begin{tabular}{llll}
\hline No & Pengetahuan & Frekuensi & Persentase \% \\
\hline 1 & Baik & 37 & 40.2 \\
2 & Cukup & 41 & 44.6 \\
3 & Kurang & 14 & 15.2 \\
& Total & 92 & 100 \\
\hline
\end{tabular}

Sumber: Data Primer (Diolah, 2021)

Berdasarkan tabel 1 menunjukan dari 92 responden, pengetahuan baik berjumlah 37 orang (40,2\%), berpengetahuan cukup sebesar 44, 6\% dan berpengetahuan yang kurang mengenai masker 15,2\%.

2. Lingkungan

Faktor lingkungan dapat mempengaruhi perilaku penggunaan masker. Perilaku tersebut ditunjukkan di dalam tabel di bawah ini.

Tabel 2. Distribusi Frekuensi Lingkungan Penggunaan Masker Pada Mahasiswi Akbid Saleha Tahun 2021.

\begin{tabular}{llll}
\hline No & Lingkungan & Frekuensi & Persetasi \% \\
\hline 1 & Baik & 53 & 57.6 \\
2 & Kurang baik & 39 & 43.2 \\
& Total & 92 & 100 \\
\hline \multicolumn{3}{l}{ Sumber: Data Primer (Diolah, 2021) }
\end{tabular}

Berdasar kan tabel 2 menunjukkan dari 92 responden lingkungan yang baik berjumlah 53 orang (57.6\%), dan lingkungan kurang baik sebesar 43,2\%. 


\section{Journal of Pharmaceutical and Health Research}

\section{Vol 3, No 1, Februari 2022, pp. 19-22}

ISSN 2721-0715 (media online)

DOI 10.47065/jharma.v3i1.1323

3. Perilaku

Tabel 3. Distribusi Frekuensi perilaku Penggunaan Masker Pada Mahasiswi Akbid Saleha Tahun 2021

\begin{tabular}{llll}
\hline No & Perilaku & Frekuensi & Persentase \% \\
\hline 1 & Positif & 58 & 63 \\
2 & Negatif & 34 & 36.9 \\
& Total & 92 & 100 \\
\hline
\end{tabular}

Berdasarkan tabel 3 menunjukkan dari 92 responden yang perilaku Positif berjumlah 58 orang (63\%).

4. Pengaruh pengetahuan terhadap kurangnya kesadaran penggunaan masker

Tabel 4. Distribusi responden pengaruh pengetahuan terhadap kurangnya kesadaran penggunaan masker pada mahasiswi Akbid Saleha tahun 2021

\begin{tabular}{|c|c|c|c|c|c|c|c|c|}
\hline \multirow{3}{*}{ No } & \multirow{3}{*}{ Pengetahuan } & \multicolumn{4}{|c|}{ Penggunaan Masker } & \multirow{2}{*}{\multicolumn{2}{|c|}{ Total }} & \multirow{2}{*}{$P$ value } \\
\hline & & \multicolumn{2}{|c|}{ Memakai } & \multicolumn{2}{|c|}{ TidakMemakai } & & & \\
\hline & & $\mathrm{F}$ & $\%$ & $\mathrm{~F}$ & $\%$ & $\mathrm{~F}$ & $\%$ & \\
\hline 1 & Baik & 37 & 100 & 0 & 0 & 37 & 100 & \\
\hline 2 & Cukup & 11 & 26,8 & 11 & 50 & 41 & 100 & 0,000 \\
\hline \multirow[t]{2}{*}{3} & Kurang & 0 & 0 & 14 & 15,2 & 14 & 100 & \\
\hline & Total & 48 & 52,2 & 44 & 47,8 & 92 & 100 & \\
\hline
\end{tabular}

Sumber: Data Primer (Diolah, 2021, SPS25)

Berdasarkan tabel 4 di atas ditemukan bahwa pengaruh pengetahuan dengan kurangnya kesadaran mahasiswi Akbid Saleha dalam penggunaan masker dari 92 responden maka ada mahasiswi Akbid saleha yang memiliki pengetahuan baik dengan memakai masker sebanyak 37 orang (100\%), sementara yang tidak memakai masker tidak ada. Untuk pengetahuan cukup ada sebanyak 41 orang $(100 \%)$, dengan memakai masker ada 11 orang dan tidak memakai masker sebanyak 30 orang. Berdasarkan tabel Chi-square test menunjukkan p-value sebesar $0,000<0,05$ maka ada pengaruh pengetahuan mahasiswi Akbid Saleha Banda Aceh.

5. Pengaruh lingkungan terhadap penggunaan masker

Tabel 5. Distribusi responden pengaruh lingkungan terhadap kurangnya kesadaran penggunaan masker pada mahasiswi Akbid Saleha tahun 2021

\begin{tabular}{|c|c|c|c|c|c|c|c|c|}
\hline \multirow{3}{*}{ No } & \multirow{3}{*}{ Lingkungan } & \multicolumn{4}{|c|}{ Penggunaan Masker } & \multirow{2}{*}{\multicolumn{2}{|c|}{ Total }} & \multirow{2}{*}{$\mathrm{P}$ value } \\
\hline & & \multicolumn{2}{|c|}{ Memakai } & \multicolumn{2}{|c|}{ Tidak Memakai } & & & \\
\hline & & $\mathrm{f}$ & $\%$ & $\mathrm{f}$ & $\%$ & $\mathrm{~F}$ & $\%$ & \multirow{4}{*}{0,000} \\
\hline 1 & Baik & 48 & 90,6 & 5 & 9,4 & 53 & 100 & \\
\hline \multirow[t]{2}{*}{2} & Kurang & 0 & 0 & 39 & 42,4 & 39 & 100 & \\
\hline & Total & 48 & 52,2 & 44 & 47,8 & 92 & 100,0 & \\
\hline
\end{tabular}

Sumber: Data Primer (Diolah, 2021, SPSS25)

Berdasarkan table 5 di atas ditemukan bahwa pengaruh lingkungan dengan kurangnya kesadaran mahasiswi Akbid Saleha dalam penggunaan masker dari 92 responden maka ada sebanyak 53 (100\%) mahasiswi Akbid saleha yang memiliki lingkungan baik dengan memakai masker sebanyak 48 orang, sementara yang tidak memakai masker 5 orang. Berdasarkan table Chi-square test menunjukkan p-value sebesar 0,000 <0,05 maka ada pengaruh lingkungan dengan kurangnya kesadaran penggunaan masker pada mahasiswi Akbid Saleha Banda Aceh.

6. Pengaruh Perilaku Terhadap Penggunaan Masker

Tabel 6. Distribusi responden pengaruh perilaku terhadapnya kurangnya kesadaran penggunaan masker pada mahasiswi Akbid Saleha tahun 2021

\begin{tabular}{|c|c|c|c|c|c|c|c|c|}
\hline \multirow{3}{*}{ No } & \multirow{3}{*}{ Perilaku } & \multicolumn{4}{|c|}{ Penggunaan Masker } & \multirow{2}{*}{\multicolumn{2}{|c|}{ Total }} & \multirow{3}{*}{$\begin{array}{c}P \text { value } \\
0,000\end{array}$} \\
\hline & & \multicolumn{2}{|c|}{ Memakai } & \multicolumn{2}{|c|}{ TidakMemakai } & & & \\
\hline & & $\mathrm{F}$ & $\%$ & $\mathrm{~F}$ & $\%$ & $\mathrm{~F}$ & $\%$ & \\
\hline 1 & Positif & 48 & 52,2 & 9 & 9,8 & 57 & 100 & \\
\hline \multirow[t]{2}{*}{2} & Negatif & 0 & 0 & 35 & 38, & 32 & 100 & \\
\hline & Total & 48 & 52,2 & 44 & 47,8 & 92 & 100 & \\
\hline
\end{tabular}

Sumber: Data Primer (Diolah, 2021, SPS25)

Berdasarkan tabel 6 di atas ditemukan bahwa pengaruh perilaku dengan kurangnya kesadaran mahasiswi Akbid Saleha dalam penggunaan masker dari 92 responden maka ada sebanyak 57 (100\%) mahasiswi Akbid saleha yang memiliki perilaku positif dengan memakai masker sebanyak 48 orang, sementara yang tidak memakai masker 9 orang. Berdasarkan table Chi-square test menunjukkan p-value sebesar 0,000<0,05 maka ada pengaruh perilaku dengan kurangnya kesadaran penggunaan masker pada mahasiswi Akbid Saleha Banda Aceh. 


\section{Journal of Pharmaceutical and Health Research}

\section{Vol 3, No 1, Februari 2022, pp. 19-22}

ISSN 2721-0715 (media online)

DOI 10.47065/jharma.v3i1.1323

Hasil penelitian menunjukkan bahwa ada pengaruh. Berdasarkan table Chi-square test menunjukkan p-value sebesar 0,000 $<0,05$ maka ada pengaruh perilaku dengan kurangnya kesadaran penggunaan masker pada mahasiswi Akbid Saleha Banda Aceh.

\section{KESIMPULAN}

Berdasarkan table Chi-square test menunjukkan p-value sebesar 0,000 $<0,05$ maka ada pengaruh pengetahuan mahasiswi Akbid Saleha Banda Aceh dengan kurangnya kesadaran penggunaan masker. Berdasarkan table Chi-square test menunjukkan p-value sebesar $0,000<0,05$ maka ada pengaruh lingkungan dengan kurangnya kesadaran penggunaan masker pada mahasiswi Akbid saleha Banda Aceh. Berdasarkan tabel Chi-square test menunjukkan p-value sebesar 0,000 $<0,05$ maka ada pengaruh perilaku dengan kurangnya kesadaran penggunaan masker pada mahasiswi Akbid Saleha Banda Aceh.

\section{DAFTAR PUSTAKA}

Aisyah, D. N., Kiasatina, T., Gusti, G. I., Adisasmito, W., Manikam, L., \& Kozlakidis, Z. (2021). Health protocol compliance integrated monitoring system to inform public health actions during the COVID-19 pandemic in Indonesia. The Lancet, 398 , S18. https://doi.org/10.1016/s0140-6736(21)02561-7

Anggoro Saputro, A., Dwi Saputra, Y., \& Budi Prasetyo, G. (2020). Analisis Dampak Covid-19 Terhadap Kesadaran Masyarakat Dalam Penerapan Protokol Kesehatan. Jurnal Porkes, 3(2), 81-92. https://doi.org/10.29408/porkes.v3i2.2865

Bartram, J., Sims, J., \& Chartier, Y. (2009). Water, sanitation and hygiene standards for schools in low-cost settings. https://books.google.com/books?hl=id\&lr=\&id=u2i_Igq7-

NwC\&oi=fnd\&pg=PR7\&dq=World+Health+Organization.$+2020 .+$ Water, + Sanitation + And + Hygiene+Standards + For + School + In+Low-Cost+Settings.+Switzerland:+Who+Press.\&ots=RrgszaEyKs\&sig=ezfUOjeqmUhfv0gGc2RC09Fx 7ko

Dewi, R., \& Apriliani, I. (2020). Studi Fenomenologi Persepsi Masyarakat Dalam Penerapan Protokol Covid-19. Real in Nursing Journal, 4(1), 44-49.

Depkes. (2017). Profil Kesehatan Indonesia Tahun 2017. https://r2kn.litbang.kemkes.go.id/handle/123456789/65231

Notoatmodjo, S. (2003). Pendidikan dan perilaku kesehatan. https://r2kn.litbang.kemkes.go.id/handle/123456789/77014

Notoatmodjo, S. (2007). Promosi kesehatan \& ilmu perilaku. https://r2kn.litbang.kemkes.go.id/handle/123456789/77273

Sari, R. K. (2021). Identifikasi Penyebab Ketidakpatuhan Warga Terhadap Penerapan Protokol Kesehatan 3M Di Masa Pandemi Covid19. Jurnal AKRAB JUARA, 6(1), 84-94.

Saputro AA, Saputra YD, Prasetyo GB. (2020). Drug treatment options for the 2019-new coronavirus (2019-nCoV). Jstage.Jst.Go.Jp, 14(1), 69-71. https://doi.org/10.5582/bst.2020.01020

W. H.O (2020). Rational use of personal protective equipment for coronavirus disease ( COVID-19) and considerations during severe shortages: interim guidance, 6 April 2020. https://apps.who.int/iris/bitstream/handle/10665/331695/WHO-2019-nCovIPC_PPE_use-2020.3-ara.pdf 